\title{
GEOGRAFI DESA DAN PENGERTIAN DESA
}

\author{
Oleh: Dilahur
}

\begin{abstract}
$\overline{\text { ABSTRACT }}$
Rural geography constitutes the branch of geography which specializes the study about the rural. Rural constitutes the object of study to be traced by geography viewpoint i.e. spatial approach, ecological approach and regional complex approach. As a sub-discipline of geography the rural geography just came into being in 1960 desennary. It was concerning with the less attentiveness of geography to poverty case in the rurals of developing countries. The study has been increasing rapidly conforming to its young age.

The main problem that emerge to solve is about definition concerning with the both comprehension of geography and rural. Rural geography maintains the study based on geography approach while according to geography viewpoint rural constitute as a region.
\end{abstract}

\section{$\overline{\text { ABSTRAK }}$}

Geografi desa merupakan cabang geografi yang mengkhususkan diri pada study pedesaan. Desa merupakan obyek studi yang dikaji dari sudut pandang geografi yaitu pendekatan keruangan, pendekatan ekologi dan pendekatan komplek wilayah. Geografi desa sebagai sub disiplin geografi belum lama yaitu baru pada masa dasa warsa 1960-an. Hal ini disebabkan perhatian yang agak kurang terhadap masalah kemiskinan di daerah pedesaan negara-negara berkembang. Bidang kajian berkembang dengan pesat sesuai dengan umurnya yang masih muda.

Problem utama yang muncul adalah pendefinisian baik pengertian geografi desa maupun pengertian desa. Geografi desa mengutamakan kajian dengan pendekatan geografi sedangkan desa dari sudut pandang geografi merupakan suatu wilayah.

\section{$\overline{\text { PENDAHULUAN }}$}

Geografi desa merupakan cabang dari ilmu geografi yang mengkususkan diri pada studi pedesaan. Desa merupakan obyek studi, sedang Geografi sebagai subyek studi artinya didalam mempelajari desa dan permasalahannya dilihat melalui kaca mata teori-teori geografi. Geografi sebagai suatu disiplin ilmu mempunyai ciri-ciri khusus dalam meninjau obyek studinya. Geografi selalu berbicara tentang interelasi, interaksi, interdependensi maupun integrasi antara unsur-unsur alam, manusia, ruang dan waktu, sehingga diperlukan kemampuan untuk melihat gejala, proses, 
perubahan, perkembangan maupun asosiasi-asosiasi antar unsur-unsur. "Dalam geografi terpadu (integrated geography) untuk mendekati atau menghampiri masalah dalam geografi digunakan bermacam-macam pendekatan atau hampiran (approach) yaitu pendekatan analisa keruangan (spatial analysis), analisa ekologi (ecological analysis) dan analisa kompleks wilayah (regional complex analysis)" (Bintarto dan Surastopo, 1979: 13-25).

Analisa keruangan mempelajari perbedaan lokasi mengenai sifat- sifat penting atau seri sifat-sifat penting. Ahli geografi akan bertanya faktor-faktor apakah yang menguasai pola penyebaran dan bagaimanakah pola tersebut dapat diubah agar penyebarannya menjadi lebih efisien dan lebih wajar. Dengan kata lain dapat diutarakan bahwa dalam analisa keruangan yang harus diperhatikan adalah pertama: penyebaran penggunaan ruang yang telah ada dan kedua: penyediaan ruang yang akan digunakan untuk pelbagai kegunaan yang dirancang.

Pendekatan ruang juga disebut pendekatan horisontal (A.J. Suharjo, 1983: 15), yang dimaksud adalah pengamatan terhadap penyebaran suatu fenomena tertentu yang sedang menjadi pusat perhatiannya pada suatu wilayah, sehingga nantinya akan diketahui pola hubungan atau struktur dari fenomena tersebut pada berbagai lokasi di wilayah yang bersangkutan.

Didalam berbicara tentang pendekatan keruangan ini, selalu akan dibicarakan tentang site dan situasion. Site mempunyai pengertian kondisi ruang setempat sedang situasion kaitan suatu tempat dengan ruang yang lebih luas atau tempat-tempat lainnya.

Pada pendekatan ekologi, ahli Geografi akan menitik beratnya pengamatannya terhadap interaksi antara manusia dengan lingkungannya dalam suatu ekosistem tertentu. Fenomena yang menjadi sasaran penelitiannnya dipelajari polanya, sifatnya dan kemudian dicari kaitan pengaruhnya dengan lingkungan sekitarnya yang merupakan suatu kesatuan ekosistem.

Lingkungan hidup manusia dapat digolongkan dalam beberapa kelompok yaitu lingkungan fisikal (physical environment), lingkungan biologis (biological environment) dan lingkungan sosial (social environment).

Pendekatan wilayah merupakan kombinasi antara pendekatan keruangan dengan pendekatan ekologi. Dalam pendekatan ini wilayah-wilayah yang menjadi ajang penelitiannya didekati dengan dasar konsep areal defferentiation yaitu suatu konsep yang mengetengahkan bahwa interaksi antar wilayah akan berkembang karena pada hakekatnya terdapat perbedaan karakteristik antara wilayah yang satu dengan wilayah lainnya. 
Dalam pendekatan ini diperhatikan pula penyebaran fenomena yang menjadi sasaran penelitian serta interaksi antara manusia dengan lingkungannya untuk dipelajari kaitankaitannya. Dalam kaitannya dengan pendekatan ini juga termasuk aspekaspek peramalan wilayah dan perencanaan wilayah. Melalui pendekatan Geografi inilah obyek studi dalam hal ini daerah pedesaan akan dipelajari.

\section{SEJARAH, RUANG LING- KUP DAN PENGERTIAN GEOGRAFI DESA}

Geografi desa merupakan suatu studi dalam bidang ilmu Geografi yang termasuk dalam kelompok studi Geografi Manusia. Munculnya Geografi desa sebagai suatu studi dalam ilmu Geografi yang berdiri sendiri sebagai sub-disiplin ilmu belum begitu lama. Barulah disekitar akhir dasawarsa 1960-an Geografi Pedesaan mencapai bentuknya yang lebih nyata. Kelambanan pemunculan Geografi Pedesaan sebagai studi yang berdiri sendiri itu, kemungkinan dikarenakan kurangnya perhatian para ilmuwan Geografi pada waktu yang lampau terhadap masalah-masalah sosial ekonomi di daerah pedesaan. Perhatian ini barulah mulai nampak disekitar tahun 1950-an, yang nampaknya bersamaan dengan perhatian dunia terhadap masalahmasalah kemiskinan yang untuk sebagian besar diderita oleh pendu- duk pedesaan di negara-negara berkembang.

Kurangnya perhatian para ahli Geografi terhadap masalah-masalah sosial ekonomi daerah pedesaan pada waktu yang lampau dapatlah dipahami, mengingat ilmu pengetahuan yang pada umumnya yang bersumber dari dunia Barat dengan struktur ekonomi industrialistik memberikan suasàna bagi para ilmuan Geografi Barat menjadi kurang terkait perhatiannya terhadap fenomenafenomena sosial ekonomi daerah pedesaan dibandingkan dengan daerah perkotaan. Ditambah lagi adanya anggapan bahwa perubahanperubahan keadaan sosial ekonomi di daerah pedesaan berjalan sangat lamban, karenanya kurang menarik untuk melakukan penelitian-penelitian.

Karena kurangnya minat untuk melakukan penelitian-penelitian di wilayah pedesaan, sewajarnyalah apabila literatur yang membicarakan permasalahan daerah pedesaan dari ilmuwan Geografi sangat langka. barulah kemudian menjelang tahun 1970, mulai bermunculan artikelartikel mengenai daerah pedesaan yang ditulis oleh para ilmuwan Geografi. Namun tulisan-tulisan tersebut lebih banyak bersifat deskriptif dibandingkan analisisnya (Cloke dalam Suharjo, 1983).

Berhubung dengan umurnya yang relatif masih sangat muda, maka bidang permasalahan yang menjadi 
arena pembicaraan dalam studi Geografi desa masih mengalami perkembangan- perkembangan yang relalif cepat waktunya. Hingga akhir dasawarsa 1970-an ruang lingkup studi Geografi desa diwarnai oleh pandangan Geografi Tradisional. Dalam Geografi Tradisional pandangan mengenai ruang lingkup studi Geografi desa pada dasarnya dapat dibagi menjadi tiga * kelompok pandangan (Johnston, Clout, dalam Suharjo, 1983).

Pertama, kelompok yang berpendapat bahwa fokus perhatian Geografi desa adalah bidang pertanian. Dengan argumentasi bahwa pertanian merupakan faktor dominan dalam tata kehidupan penduduk daerah pedesaan. Dengan pandangan ini maka Geografi desa banyak bertumpang tindih dengan Geografi Pertanian. Untuk menekankan perbedaan antara geografi pedesaan dengan Geografi Pertanian dikemukakan bahwa: geografi pertanian memfokuskan perhatiannya pada hubungan-hubungan ekonomi dari produksi pertanian, sedangkan Geografi desa menitik beratkan perhatiannya pada hubungan-hubungan antara usaha tani dengan segala aspek kehidupan dari penduduknya.

Kedua, kelompok yang menitik beratkan perhatiannya pada permasalahan permukiman sebagai isi pokok dalam bidang studi Geografi Desa. Dengan demikian Geografi
Desa adalah identik dengan geografi Permukiman Pedesaan.

Ketiga, kelompok lainnya berpandangan bahwa disamping masalah pertanian dan permukiman, pemasalahan tata guna lahan di daerah pedesaan merupakan sasaran studi yang penting dalam Geografi Desa.

Di dalam sejarah perkembangan studi Geografi Desa maka Clout-lah yang dipandang sebagai pionimya. Clout adalah orang yang pertama-tama menyampaikan kerangka dasar studi Geografi Pedesaan untuk dapat berdiri sendiri sebagai sub-disiplin ilmu Geografi. kerangka dasar tersebut termuat dalam bukunya yang berjudul "Rural Geography" An Introductory Survey" yang terbit tahun 1972. Dalam situasi yang langka akan literatur yang membahas permasalahan daerah pedesaan dari sudut pandangan Geografi, di Indonesia telah terbit untuk yang pertama kali buku karangan Prof. Drs. Bintarto dengan judul "Pengantar Geografi desa" pada tahun 1969. Buku ini bermaksud mengisi kekosongan akan literatur pedesaan dari sudut pandangan seorang ahli Geografi.

Pada waktu orang masih mencaricari isi dari studi geografi Desa ini, Bowler (1975) mencoba menginventarisir pekerjaan-pekerjaan penelitian yang dilakukan oleh para ilmuan Geografi. Tulisan- tulisan dari hasil penelitian yang telah diinventarisir oleh Bowler itu kemudian dikelom- 
pokkan menjadi tujuh bidang penelitian, dan kemudian diperinci lagi ke dalam aspek-aspek penelitian yang ber hubungan dengan penelitian tadi. Ketujuh bidang penelitian tersebut adalah: (1) pertanian, (2) kehutanan, (3) permukiman, (4) kependudukan, (5) transportasi, (6) rekreasi dan turisme, (7) perencanaan (pengembangan) pedesaan. Sudah barang tentu dalam perkembangannya kemudian, bidang studi Geografi desa dapat bervariasi dan jumlahnya juga tidak hanya terbatas pada tujuh bidang penelitian itu.

Dalam buku "progress in Rural Geography" yang untuk pertama kalinya terbit tahun 1983 ini terdapat sepuluh artikel terpilih. Tiga diantara sepuluh artikel tersebut merupakan artikel dari permasalahan-permasalahan tradisional (permukiman, tataguna lahan, pertanian). Menurut Michael Pacione, editornya, buku tersebut diterbitkan dengan maksud untuk memonitor perkembangan studi Geografi yang menekuni permasalahan pedesaan. Diharapkan kemudian akan terjadinya saling kontak diantara ilmuwan Geografi (Desa) serta dapat memonitor perkembangan studi Geografi desa, baik dari segi isi, metodologi dan teorinya. Dari segi isi, dikemukakan bahwa Geografi Desa tidak lagi secara tradisional hanya menyangkut masalah-masalah yang berhubungan dengan pertanian, permukíman dan pola-pola peng- gunaan lahan saja, tetapi sekarang telah meliputi pula permasalahanpermasalahan pedesaan yang lain, seperti transportasi pedesaan, kesempatan kerja, perumahan, strategi pengembangan pedesaan, dan lainlainnya lagi. Dari buku "Progress in Rural Geography" terbitan pertama oleh editornya telah dipilih sepuluh buah karya tulis mengenai pokokpokok permasalahan yang berbedabeda.

Judul-judul kesepuluh karya tulis tersebut adalah :

1). The evaluation of the Settlement Pattern (Mc Bunce).

2). Landuse and Competition (A.C. Champion).

3). Structural Change in Agriculture (I.R. Bowler).

4). Population and Employment (A.W. Gilg).

5). Housing (A.W. Rogers).

6). Transport and Accessibility (D.J. Banister).

7). Rural Communities (G.J. Lewis).

8). Recreation (M.F. Tanner).

9). Resource Evaluation and Management (P.J. Cloke).

10). Rural Planning (D.R.J. Robbins).

Mengingat bahwa artikel-artikel yang termuat dalam buku "Progress in Rural Geography" tersebut ditulis oleh para ilmuan Geografi Barat, yang ditulis atas dasar pengalaman, pengamatan dan hasil penelitian daerah pedesaan di Dunia Barat, 
sudah barang tentu masih perlu dipertanyakan mengenai aplikasinya untuk daerah pedesaan di Indonesia. Tetapi setidak-tidaknya kita akan dapat mempelajari kerangka dasar pemikirannya, materinya serta metodologinya dalam menelaah pemikirannya, materinya serta metodo loginya dalam menelaah permasalahan-" permasalahan pedesaan yang terdapat dalam artikel-artikel tersebut.

Pada umumnya dalam bidang keilmuan pendefinisian suatu pengertian atau istilah merupakań suatu permasalahan tersendiri. Pendefinisian sebagai suatu usaha pembatasan obyek studi serta ruang lingkup studi walaupun sulit namun penting untuk dilaksanakan. Kesulitan ini disebabkan masing-masing ahli mempunyai pandangan-pandangan yang sering berbeda-beda, apalagi bagi cabang ilmu yang masih relatif muda seperti Geografi Pedesaan. Namun demikian seperti telah dikemukakan di depan Geografi sebagai subyek studi telah mempunyai suatu sistem pendekatan yang telah mapan yaitu dengan pendekatan keruangan, pendekatan ekologi serta pendekatan wilayah. Oleh karena itu, secara umum Geografi Desa dapat dikatakan sebagai cabang ilmu Geografi yang menjadikan desa atau daerah pedesaan sebagai obyek studi melalui pendekatan keruangan, pendekatan ekologi, serta melalui pendekatan keruangan, pendekatan ekologi, serta pendekatan wilayah. Dr. AJ. Suharjo, M.A. memberikan definisi yang lebih menekankan pada dinamika sosial ekonomi daerah pedesaan dengan definisi: Geografi Pedesaan adalah suatu cabang ilmu Geografi yang mempelajari fenomena sosial dan ekonomi beserta perubahan-perubahannya di daerah pedesaan.

Dari pengertian-pengertian tersebut dapat diketahui bahwa lingkup studi Geografi Pedesaan yang luas, dapat meliputi satu desa maupun meliputi suatu kawasan pedesaan.

\section{DESA DAN UNSUR-UNSUR DESA DITINJAU DARI SEGI GEOGRAFI}

Perkataan "Dusun" "Desi" (ingat perkataan Swadesi), seperti juga halnya dengan perkataan "negara", "Negari", "Negory" (dari perkataan negaram), asalnya dari perkataan Sanskrit, yang artinya tanah air, tanah asal, tanah kelahiran dan seterusnya. Perkataan desa hanya dipakai di Jawa, Madura dan Bali (Sukandar Wiraatmaja, 1972: 11). Pada daerah lainnya dipakai istilah-istilah lain yang memilih pengeritian yang sama seperti dusun di Sumatera Selatan, dusun di Maluku, gampong dan menuasah di Aceh Kota, uda atau huta di Batak dan sebagainya. Namun demikian untuk menterjemahkan tentang pengertian desa dapat ditinjau dari berbagai segi, sehingga tidak terdapat rumusan yang seragam. 
Hal ini bila kita lihat beberapa definisi yang dikutip oleh R. Bintarto (1983: 1):

1. Desa adalah suatu tempat yang terutama untuk tempat tinggal dan bahkan terutama sebagai pusat perdagangan. Desa-desa itu disusun sebagian besar oleh rumah-rumah pertanian dan dihubungkan dengan bangunan tambahan (Finch, 1957).

2. Desa adalah meliputi suatu kesatuan organisasi kehidupan sosial didalam daerah yang terbatas (William, 1963).

3. Sebuah desa adalah bukan hanya kumpulan dari rumah-rumah tempat tinggal.

Desa adalah sebuah daerah pertanian yang padat dengan batas-batas tertentu, biasanya 50 1000 acre luasnya $(1$ acre $=4,047 \mathrm{~m}$ persegi) (Mitra, 1962).

4. Dapat dikatakan dengan tegas bahwa sebuah desa adalah tempat pemusatan penduduk dengan jumlah antara 250 sampai 2500 orang (Bunner, 1952).

5. Penjelasan resmi pasal 1 , UU 1948/22 menyatakan bahwa dengan desa dimaksudkan daerah yang terdiri dari satu atau lebih dari satu (di sumatra : Negeri, Marga, dan sebagainya) yang digabungkan hingga merupakan satu daerah yang mempunyai syarat-syarat cukup untuk berdiri menjadi daerah otonom yang berhak mengatur dan mengurus rumah tangganya sendiri.
Dalam lingkungan desa atau kota kecil yang berotonom dengan sendirinya sudah tidak akan terdapat lagi desa biasa yang mempunyai pemerintahan sendiri, sebab desa atau kota kecil itu adalah pemerintah daerah-daerah terbawah (The Liang Gie, 1976:27).

6. Desa ialah satu kesatuan hukum dimana bertempat tinggal suatu masyarakat yang berkuasa mengadakan pemerintahan sendiri (Sutardjo Kartohadikusuma: 1953: 2).

7. Sebenarnya desa itu adalah suatu hasil perpaduan antara kegiatan sekelompok manusia dengan lingkungannya. Hasil dari perpaduan itu ialah suatu ujud atau kenampakan di muka bumi yang ditimbulkan oleh unsur-unsur fisiografi, sosial, ekonomi, politik dan kultural yang saling berinteraksi antar unsur tersebut dan juga dalam hubungannya dengan daerahdaerah lain. Definisi lain, yaitu oleh Sukandar Wiraatmaja (1972:12) menyatakan yang dinamakan desa ialah suatu kesatuan hukum, dimana bertempat tinggal suatu masyarakat yang berkuasa mengadakan pemerintahan sendiri. Desa terjadi dari hanya satu tempat kediaman masyarakat saja, ataupun terjadi satu induk dan beberapa tempat kediaman sebagian daripada 
masyarakat hukum yang terpisah yang merupakan kesatuan-kesatuan tempat tinggal sendiri, kesatuan-kesatuan mana dinamakan pedukuhan, kampung, cantilan, beserta tanah pertanian, tanah perikanan darat (empang, tambak, dan sebagainya), tanah hutan dan tanah belukar.

Perbedaan pengertian ini sulit untuk dapat dikompromikan $*$ karena adanya perbedaan persepsi dan perbedaan latar belakang. Adalah kesulitan yang besar untuk memperoleh pengertiaan umum yang dapat diterima semua fihak. Hal ini dapat diberikan penjelasan berdasarkan berbagai rumusan di atas.

Ditinjau dari jumlah penduduknya, tidak dapat ditentukan dengan pasti yaitu antara $250-2500$. Di beberapa negara misalnya di Kanada suatu permukiman yang berpenduduk lebih dari 1000 jiwa telah diberi status kota, di Amerika lebih dari 2.500 jiwa diberi status kota sedang di India desa-desa bisa berpenduduk lebih dari 30.000 baru diberi status kota (harm J. de Blij : $1977: 240)$.

Demikian pula luas, fungsi, lapangan kerja dan sebagainya tidak dapat digunakan dengan tepat untuk memberi batasan desa. Namun demikian dapat dicatat untuk memberi batasan desa. Namun demikian dapat dicatat bahwa desa mempunyai hubungan yang erat dengan lingkungan alam dan kegiatan pada bidang primer atau pengolahan produksi primer.

Hal ini seperti dijelaskan lebih lanjut oleh Harm J. de Blij (1977 : 241), desa-desa dengan demikian, memiliki variasi yang besar dalam ukuran dan bentuknya. Kesamaan dari padanya adalah orientasinya pada bidang pertanian. Sebagian besar penduduk nya bekerja di bidang pertanian; rumah-rumah adalah rumah-rumah petani dan bangunan tambahan berupa gudang-gudang, lumbunglumbung dan bangunan-bangunan lain yang sejenis. Di dalam desa- desa mungkin terdapat tempat ibadah, barangkali juga sebuah klinik kesehatan, sebuah sekolah dan tempat pertemuan umum; desa-desa yang besar mungkin menampung pula orang-orang yang berprofesi sebagai guru, dokter dan pemimpin agama, juga pengusaha toko dan ahli perbengkelan/mekanik. Tetapi mereka semua melayani penduduk yang sebagian besar terikat pada lahannya. Oleh karena itu dalam usaha ke arah penyusunan definisi desa perlu diperhatikan tiga unsur desa yang penting yaitu :

1. Unsur daerah : Dalam artian tanah-tanah didesayangproduktif dan yang tidak produktif, beserta penggunaannya, termasuk juga unsur lokasi, luas dan batas yang merupakan unsur geografi setempat. 
2. Penduduk, dalam hal ini meliputi jumlah, pertambahan, kepadatan, penyebarandanmatapencaharian penduduk setempat.

3. Tatakehidupan, dalamhal inipola tata pergaulan dan ikatan- ikatan pergaulan tata desa. Jadi seluk beluk kehidupan masyarakat desa (rural society) (R. Bintarto, 1977:15).

Yang perlu diperhatikan adalah bahwa unsur-unsur desa tersebut bukanlah unsur yang statis, tetapi merupakan bagian tak terpisahkan dari daerah lainnya sehingga akan mengikuti perubahan dan perkembangan yang akan merubah pola pemanfaatan tanah dan lingkungan, pola kependudukan dan pola tata pergaulan masyarakatnya. Dengan demikian desa secara individual maupun kawasan pedesaan ditinjau dari segi geografi merupakan sebuah wilayah. Oleh karena itu untuk memahami desa maupun kawasan pedesaan serta untuk memahami ma- salah-masalah pedesaan diperlukan pendekatan kewilayahan atau dengan kata lain menempatkan didalam konteks kewilayahan.

\section{$\overline{\text { PENUTUP }}$}

Perkembangan Geografi Desa agak terlambat berhubung problem perkotaan lebih meonjol pada masa-masa perkembangan Industri di Eropa. masalah-masalah pedesaan mulai dirasakan setelah munculnya masalah kemiskinan di negara-negara sedang berkembang.

Dari sudut pandang Geografi desa dan kawasan pedesaan merupakan suatu wilayah yang tidak dapat dilepaskan dari wilayah di sekitarnya. Konsekuensinya kajian geografi terhadap desa dan kawasan pedesaan hendaknya ditekankan pada pendekat an kewilayahan, dengan demikian kajian tersebut akan memberikan konstribusi yang berarti terhadap pembangunan desa/kawasan pedesaan tersebut. 


\section{$\overline{\text { DAFTAR PUSTAKA }}$}

Bintarto R., Surastop H, 1979, Metode Analisa Geografi, Jakarta, LP3ES.

Bintarto, R, 1983, Geografi Desa, Yogyakarta, UP. Spring. , 1983, Interaksi Desa-Kota dan Permasalahannya, Jakarta, Ghalia Indonesia.

Clout, Hugh D., 1972, Rural Geography, an Introductory Survey, Oxford, Pergamon Press.

Harm, J. de Blij, Human Geography; Culture, Society, and Space, New York, John Wiley and Sons.

Pacione, Michael (ed), 1983, Progress in Rural Geography, London, Croom Helm.

Suharjo, AY, 1983, Geografi Pedesaan dan Pembangunan, Pidato Pengukuhan Jabatan Lektor kepala dalam Bidang Geografi Pedesaan Pada Fakultas Geografi Universitas Gajah Mada. 